\title{
Erratum to: Aggregation and Competitive Exclusion: Explaining the Coexistence of Human Papillomavirus Types and the Effectiveness of Limited Vaccine Conferred Cross-Immunity
}

\section{E. K. Waters ${ }^{1}$}

Published online: 3 June 2016

(C) Springer Science+Business Media Dordrecht 2016

\section{Erratum to: Acta Biotheor (2012) 60:333-356}

\section{DOI 10.1007/s10441-012-9161-5}

The symbolic expression in the second paragraph of Sect. 3 has been published incorrectly. The correct expression is as follows:

$$
\left(1-\frac{\gamma N}{\alpha}\right) / m
$$

The online version of the original article can be found under doi:10.1007/s10441-012-9161-5.

E. K. Waters

edward.waters@nd.edu.au

1 The University of Notre Dame Australia, PO Box 944, Broadway, NSW 2007, Australia 